XIV Российская национальная конференция по сейсмостойкому строительству и сейсмическому районированию (с международным участием). Сборник материалов

УДК 624.042.7

DOI 10.37153/2687-0045-2021-14-135-136

\title{
ОСОБЕННОСТИ РАСЧЕТНОГО ОБОСНОВАНИЯ ПАРАМЕТРОВ ДИНАМИЧЕСКИХ ГАСИТЕЛЕЙ КОЛЕБАНИЙ ДЛЯ СЕЙСМОЗАЩИТЫ ЗДАНИЙ И СООРУЖЕНИЙ
}

Уздин А.М., д.т.н., проф. (Петербургский государственный университет путей сообщения), uzdin@mail.ru.

Нестерова О.П., к.т.н, доц. (Санкт-Петербургский государственный архитектурностроительныйуниверситет), nеona975@уапdех.ru.

Федорова М.Ю., к.ф.-м.н., дои. (Санкт-Петербургский государственныий университет), mgfed@mail.ru.

Гуан Ю Хай, Ph.D. Китай (Китайский университет нефти), quапуоuhai@upc.edu.cn.

Целью исследования является оценка эффективности и особенностей подбора оптимальных параметров динамических гасителей колебаний (ДГК) при сейсмических воздействиях. Особое внимание уделено работе ДГК большой массы. Рассматривается влияние используемой модели учета демпфирования в системе сооружение - гаситель на оптимальные параметры и эффективность ДГК.

В исследовании было рассмотрено три модели учета затухания:

- затухание по Е.С. Сорокину в сооружении и пружине ДГК;

- вязкое затухание, эквивалентное гистерезисному, в сооружении и пружине ДГК;

- гистерезисное затухание в сооружении и пружине ДГК и дополнительное вязкое затухание в связи между гасителем и сооружением.

Перечисленные модели учета затухания были рассмотрены для двух систем: с малым демпфированием в основной системе $2.5 \%$ критического и с большим демпфированием 17.5\% критического. Для каждой из систем задавался гаситель с относительной массой $v=0.1$ и гаситель большой массы с $v=1$. Для рассмотренных систем были сделаны следующие выводы:

1. Оптимизация параметров ДГК существенно зависит от относительной массы ДГК и затухании в защищаемом сооружении. При относительной массе гасителя v>0.5 оптимальное демпфирование в пружине ДГК существенно возрастает. Такую массу мы называем большой массой.

2. Для ДГК большой массы оптимальное демпфирование в пружине ДГК достаточно велико и превышает $50 \%$ от критического значения. В связи с этим модель учета затухания влияет на результат оптимизации параметров гасителя и на его расчетную эффективность. При этом чем больше затухание в защищаемом сооружении, тем значительнее различия в эффективности и оптимальных параметрах ДГК, т.е. тем аккуратнее следует подходить к моделированию демпфирования в элементах ДГК.

3. Для ДГК малой массы способ учета затухания не влияет на результат подбора параметров ДГК и его эффективность при малом затухании в защищаемом сооружении и влияет незначительно при большом затухании.

4. Затухание в сооружении и пружине гасителя - гистерезисное. Данное затухание обычно не превышает 5-7\% от критического и адекватно оценивается с помощью 
XIV Российская национальная конференция по сейсмостойкому строительству и сейсмическому районированию (с международным участием). Сборник материалов

эквивалентного вязкого затухания. В то же время между ДГК и защищаемым сооружением должна устанавливаться дополнительная демпфирующая связь, которая может быть выполнена различным образом: в виде жидкостного демпфера, пластического демпфера, демпфера сухого трения и др. В связи с этим задача выбора подходящей модели учета демпфирования в системе сооружение - гаситель для ДГК большой массы приобретает принципиальное значение. 